\title{
ТЕРИТОРІАЛЬНІ ПРОЦЕСИ
}

https://doi.org/10.15407/dse2019.03.113

УДК 332(477)

JEL CLASSIFICATION: R10

\section{С.А. РОМАНЮК}

д-р екон. наук, директор

Інститут Вища школа державного управління

Національної академії державного

управління при Президентові України

03057, Украина, м. Київ, вул. Антона Цедіка, 20

E-mail: rosand@i.ua

ORCID 0000-0003-1219-1513

\section{РЕГІОНАЛЬНИЙ РОЗВИТОК В УКРАЇНІ: МИНУЛЕ, СУЧАСНЕ. МАЙБУТНЕ?}

Стаття присвячена проблемам формування державної політики регіонального розвитку в умовах посилення тенденцій територіальної економічної концентрації в Україні. Метою статті є формування пропозицій зі здійснення державної політики регіонального розвитку на період після 2020 року на основі узагальнення тенденцій розвитку регіонів України та дослідження сучасних підходів до територіального розвитку в європейських країнах. На основі використання дифузійної моделі розвитку регіонів за період 2004-2017 років виявлено подальше поширення процесів гальмування економічної динаміки у ключових промислових областях країни на фоні концентрації розвитку в інших територіях, що корелює зі зміною щільності населення. Охарактеризовані нові концепції, які сьогодні впроваджсються у розвинених країнах і можуть бути використані в умовах України (регіональні інноваційні системи). 3'ясовано, що найефективнішим підходом держави до територіального розвитку є територіально спрямоване втручання, що передбачає інтеграцію сфер державної політики в різних секторах економіки та інвестиційних інтервенцій у намаганні покращити їх ефективність $і$ запровадити більш інтегрований підхід до регіонального та місцевого розвитку. Обгрунтовано, що нова державна стратегія регіонального розвитку, яка буде сформована на період після 2020 року, має враховувати ризики територіальної економічної концентрації, що продовжують підвищуватися, застосовуючи інтегровані підходи у політиці і в управлінні.

Ключові слова: регіональний розвиток, територіальна економічна концентрація, інтегральні стратегії розвитку, регіональний інноваційний розвиток. 


\section{S.A. Romanyuk}

Dr. Sc. (Economics), the Director of High School of Public Administration

the Head of Department of public administration

National Academy of Public Administration

under the President of Ukraine

03057, Ukraine, Kyiv, Anton Tsedika str., 20

E-mail: rosand@i.ua

ORCID 0000-0003-1219-1513

\section{REGIONAL DEVELOPMENT IN UKRAINE: PAST, TODAY. FUTURE?}

The purpose of this article is to formulate proposals for the implementation of the state policy of regional development for the period after 2020 based on the growing trends in the development of regions in Ukraine and the study of modern approaches to territorial development in European countries. In particular, using the diffusion model of territorial development for the period of 2004-2017 revealed further spread of processes of inhibition of economic dynamics in the key industrial regions of the country against the backdrop of concentration of development in other territories; it correlates with the change in population density. The new concepts being implemented in the developed countries and can be used in the conditions of Ukraine (regional innovation systems) are described. It is found that one of the most promising modern approaches to the formation of strategic directions of regional development, which received support in the framework of the program period 2014-2020 of the regional development policy of the $E U$, was the introduction of strategies that include integrated development based on the concept of territorialdirected interference by national authorities or supranational structures (place-based approaches). It is proved that the Polish government demonstrates the case of the improvement of the relevant mechanism of state regulation for regional development. This is evidenced by a four-year Strategy for Responsible Development, which defines the direction of Poland's development until 2020. Its implementation is carried out through the introduction of nine modernized sectoral integrated strategies, which in turn are based on strategic programs. The purpose is to create conditions for the formation of high incomes and better quality of life, while ensuring the competitiveness of the national economy at the same time. It is substantiated that the new state strategy for regional development, which will be formed after 2020, should take into account the risks of territorial economic concentration that continue to increase, using integrated approaches in politics and governance.

Keywords: regional development, territorial economic concentration, integral strategies of development, regional innovate development

\section{С.А. Романюк}

д-р экон. наук, директор

Институт Высшая школа государственного управления

Национальная академия государственного

управления при Президенте Украины

03057, Украина, г. Киев, ул. Антона Цедика, 20

E-mail: rosand@i.ua

ORCID 0000-0003-1219-1513

\section{РЕГИОНАЛЬНОЕ РАЗВИТИЕ В УКРАИНЕ: ПРОШЛОЕ, НАСТОЯЩЕЕ. БУДУЩЕЕ?}

Статья посвящена проблемам формирования государственной политики регионального развития в условиях нарастания тенденций территориальной экономической концентрации в Украине. Цель статьи формирование предложений по осуществлению государственной политики регионального развития на период после 2020 года на основе обобщения тенденций развития регионов Украины а также анализа современных подходов к территориальному развитию в европейских странах. На основе использования диффузионной модели территориального развития за период 2004-2017 годов выявлено дальнейшее распространение процессов торможения экономической динамики в ключевых промышленных регионах страны на фоне концентрации развития в других территориях, что коррелирует с изменением плотности населения. Охарактеризованы новые концепции, которые сегодня применимы в развитых странах и могут быть использованы в условиях Украины (региональные инновационные системы). Установлено, что наиболее эффективный подход к территориальному развитию - территориально направленное воздействие, предусматривающее интеграцию сфер государственной политики в разных 
секторах экономики, а также инвестиционных интервенций для улучшения их эффективности и использования более интегрированного подхода к региональному и местному развитию. Обосновано, ито новая государственная стратегия регионального развития, которая будет сформирована на период после 2020 года, должна учитывать возрастающие риски территориальной экономической конщентрации, используя интегрированные подходы в политике и управлении.

Ключевые слова:региональное развитие, территориальная экономическая концентрация, интегральные стратегии развития, региональное инновационное развитие.

Постановка проблеми та актуальність теми. В українському науковому і політичному середовищах постійно триває пошук підходів до формування сучасних механізмів активізації соціально-економічних процесів на регіональному та місцевому рівнях. Висока динаміка регіональних диспропорцій останніх років і концентрація економічної активності лише в деяких переважно урбанізованих територіях посилюють тенденції моноцентричного розвитку, що супроводжується проблемами нерівного доступу громадян, які живуть у різних громадах, до базових послуг високої якості. Усе це вимагає визначення основних напрямів змін у державній політиці регіонального розвитку. Актуальність означеного зростає в умовах підготовки Кабінетом Міністрів України Державної стратегії регіонального розвитку, розрахованої на період після 2020 року [1]. Вітчизняні науковці відмічають недоліки цього стратегічного документа, розрахованого до 2020 року [2], зокрема те, що визначені стратегічні цілі та механізм вибору пріоритетних цілей регіонального розвитку не скориговано відповідно до зміни у внутрішньому та зовнішньому середовищі країни. В українській практиці у ході планування регіонального розвитку основну увагу приділяють розробленню стратегії (документа) та недостатню - плану ії реалізації. Логіка традиційного підходу базується на розумінні того, що якщо створено якісний документ, то його реалізація відбуватиметься автоматично та результативно. В Україні механізми та інструменти систематичного (відповідно до українського законодавства щорічного) моніторингу результативності реалізації Стратегії розробляють формально та декларативно. Технократичний підхід переважає під час стратегічного планування регіонального розвитку в Україні, що не сприяє формуванню суспільної відповідальності за ідентифікацію та розв'язання регіональних проблем. Стратегії укладають за принципом «згори-донизу» працівники департаментів економіки місцевих державних адміністрацій із незначним залученням спеціалістів на децентралізованих рівнях управління і партнерів із громадянського суспільства [3].

Одним із основних недоліків у формуванні стратегічних підходів до розвитку територій і країни в цілому є відсутність скоординованої та узгодженої в ресурсах і часі діяльності різних органів влади та органів місцевого самоврядування, тобто відсутність горизонтальної та вертикальної координації [4].

Аналіз останніх досліджень і публікацій. Серед проблем, які виникли під час формування та реалізації регіональних і місцевих стратегій розвитку до 2020 року, експерти та практики також відмічають:

- недостатньо активне залучення громадськості до розробки стратегічних документів;

- занадто широкий спектр пріоритетів, унаслідок чого залучені ресурси для реалізації стратегій розпорошуються і не створюють ефекту виникнення точок зростання;

- нерідко вибір цілей обгрунтований не об’єктивними чинниками, а більше детермінований політичними інтересами учасників стратегічного процесу, 
через що не відбувається публічного обговорення проєктів, непрозорим стає розподіл обмежених матеріальних ресурсів;

- завдання, які формуються в рамках проектів, що розробляються, часто не відповідають структурі стратегічних пріоритетів [5].

Як відмічають вітчизняні науковці, типовими для стратегій територіальних міст, селищ, сіл, зокрема об’єднаних територіальних громад, залишаються недоліки, пов'язані з:

- відсутністю єдиного підходу до розробки стратегічних документів з точки зору уявлень про зміст таких документів, обсяг і глибину опрацювання, джерел інформації, необхідної для аналізу й оцінок. Це виглядає дещо парадоксальним, адже обсяг технічної і фінансової допомоги різних міжнародних інституцій та іноземних держав місцевому розвитку за останні роки збільшився багаторазово. Це може вказувати на недостатню результативність використання такої допомоги державними та місцевими органами влади в контексті її пристосування із урахуванням територіальної специфіки розвитку;

- неузгодженістю стратегічних цілей розвитку у стратегічних документах державного, регіонального та місцевого рівня, що є наслідком відсутності чіткого порядку встановлення їх взаємозв’язку у ході розробки таких документів. Доцільно також додати до цього і відсутність механізму врахування інтересів різних громад у регіональних стратегіях;

- неврахування змін, що відбуваються, у стратегічних документах. Іншою стороною подібної проблеми є те, що суб'єкти стратегічного процесу, особливо невеликих за потенціалом громад, намагаються розробити стратегії на тривалий період, а це пов'язано зі зростанням невизначеності в умовах розвитку;

- відсутністю адекватного моніторингу виконання стратегічних документів, перевірки їх виконання після урахування, використання для моніторингу неадекватних індикаторів як на державному, так і на регіональному та місцевому рівнях;

- економічною необгрунтованістю планів і стратегій, декларативністю багатьох положень розроблених стратегій розвитку територій.

Отже, незважаючи на певний прогрес за останні більш ніж десять років, вплив на регіональний розвиток на різних територіальних рівнях залишається недостатньо ефективним і таким, що потребує суттєвого удосконалення в частині економічного, організаційного та кадрового забезпечення [6].

Метою статті є узагальнення тенденцій розвитку регіонів України, здійснення аналізу сучасних підходів до формування державної політики регіонального розвитку у розвинених країнах з метою формування відповідних пропозицій в умовах наявних тенденцій розвитку регіонів України.

Наукова новизна полягає у доповненні наявних результатів дослідження основних тенденцій розвитку регіонів України в умовах територіальної економічної концентрації упродовж 2004-2017 років.

Методи дослідження. Дослідження виконано з використанням дифузійної моделі територіального розвитку із графічним відображенням отриманих результатів. Модель використовує показники змін у таких індикаторах розвитку як економічна щільність (обсяг валового регіонального продукту на одиницю площі, у порівняльних цінах) щільність населення (чисельність наявного населення на одиницю площі) і продуктивність праці (валовий регіональний продукт на одну особу). За цими показниками регіони кластерізовано у чотири групи: регіони з позитивною динамікою економічної 
щільності та щільності населення (території динамічного розвитку); регіони із позитивною економічною динамікою та негативною динамікою щільності населення (регіони із нестійкою динамікою розвитку); регіони із негативною динамікою економічної щільності та щільності населення (окремо виділено регіони, де одночасно має місце негативна динаміка продуктивності праці - регіони у стані стійкого занепаду); регіони з позитивною динамікою щільності населення і негативною динамікою економічної щільності (регіони з нестійкою динамікою розвитку).

Виклад основного матеріалу. В регіональному розвитку України останнім часом відбуваються процеси, які відображають специфіку змін, що мають неоднозначний і суперечливий характер. Подібну оцінку висловлюють як вітчизняні, так і зарубіжні експерти, науковці, дослідники. Зокрема, як відмічає Організація економічного співробітництва та розвитку (ОЕСР), після 2010 року географічна структура розвитку в Україні повністю змінилася [7]: західні регіони загалом стали розвиватися динамічніше за східні. Створився чітко окреслений кластер розвитку, який охоплює Вінницьку, Тернопільську, Хмельницьку та Житомирську області, Черкаську та Кiровоградську області а також міську агломерацію Києва (м. Київ і Київська область). Сільські території в центрі та на Заході України, за оцінками експертів ОЕСР, стали основними факторами зростання економіки країни. I навпаки, промислові області - Запорізька, Харківська, Дніпропетровська, а також територія Донецької та Луганської областей - увійшли в рецесію ще 2012 року. Окупація Криму та збройний конфлікт на Донбасі суттєво погіршили ситуацію.

Одночасно деякі області - Вінницька, Житомирська, Волинська і Тернопільська - скористалися перевагами розвитку «легких» промислових секторів - харчової промисловості, виробництва запчастин для авто та деревообробки. Як наслідок, у період 2004-2014 років розвиток економіки був сконцентрований у кількох регіонах, які швидко розвивалися. За цей час, як стверджують фахівці, частка шести областей із найвищими темпами приросту валового регіонального продукту (ВРП) становила 93,5 \% загальнонаціонального приросту ВВП. Такий високий рівень територіальної економічної концентрації зумовлений:

- незначними результатами найбільших суб'єктів економіки на Сході, і не тільки через збройний конфлікт на Донбасі, але й у зв'язку зі скороченням темпів виробництва у Дніпропетровській та Запорізькій областях;

- найпотужнішою динамікою економіки Києва та Київської області (на ці два регіони припадало 60 \% зростання національної економіки у 20042014 рр.) [7].

Основним чинником підвищення територіальної концентрації розвитку останні два десятки років залишається Київ, де зосереджено три чверті працюючих, що мають вищу освіту, забезпечуючи понад половину сукупного приросту ВВП країни. У 2018 році 60 \% усіх прямих іноземних інвестицій, що надійшли в Україну, припадало на столицю держави. Іншим регіоном, який робить суттєвий внесок у сучасний розвиток, є Київська область.

Важливо відзначити, що суттєва економічна територіальна концентрація в Україні спостерігається вже тривалий час [8, 9]. Вона обумовлена об'єктивними чинниками, супроводжується зростанням соціально-економічних диспропорцій і становить певну загрозу посилення тенденцій територіального моноцентричного розвитку. Економічна активність переміщується у великі міста країни, а сільські населені пункти та невеликі поселення знелюднюються. Відповідним чином реагує бізнес: він зосереджується на територіях зі значною щільністю населення, що гарантує 
сталий попит на товари та послуги, одночасно полишаючи місця із низьким обсягом споживання. Як наслідок, невеликі, віддалені від місць економічної концентрації територіальні громади, навіть в умовах отримання права на нові місцеві податки в ході фіскальної децентралізації, продовжують занепадати у розвитку, оскільки позбавлені власних джерел доходів.

Таким чином зростають диспропорції у можливостях органів місцевого самоврядування вплинути на покращення надання громадянам базових послуг освітніх, соціальних, медичних, комунальних. За цих умов незворотним для держави $€$ рішення щодо рецентралізації повноважень у наданні публічних послуг: громади об'єднують, використовуючи різноманітні моделі та стимули чи примус. Власне цим пояснюється процес об’єднання територіальних громад, що триває в Україні.

Проблема полягає у тому, що продовження динамічних процесів міграції як у середині країни, так і виїзд громадян за кордон з метою пошуку гідних умов існування, постійно генеруватимуть потребу укрупнення громад, приєднання громад із малим потенціалом розвитку до місць територіальної економічної концентрації. Тенденції останніх років дають підстави для занепокоєння, що подібних точок економічної активності залишатиметься усе менше. Адже особливість сучасних проявів географічних диспропорцій полягає у тому, що країна поступово, але впевнено втрачає власний потенціал, насамперед промисловий. За останні півтора десятиліття у ключових промислових регіонах економічна динаміка гальмується, зменшується щільність населення та продуктивність праці (рис. 1).

Зокрема, Дніпропетровська, Запорізька, Донецька та Луганська області за досліджуваний період поступово опинились у становищі, коли одночасно три індикатори розвитку - економічна щільність, щільність населення та продуктивність - мають

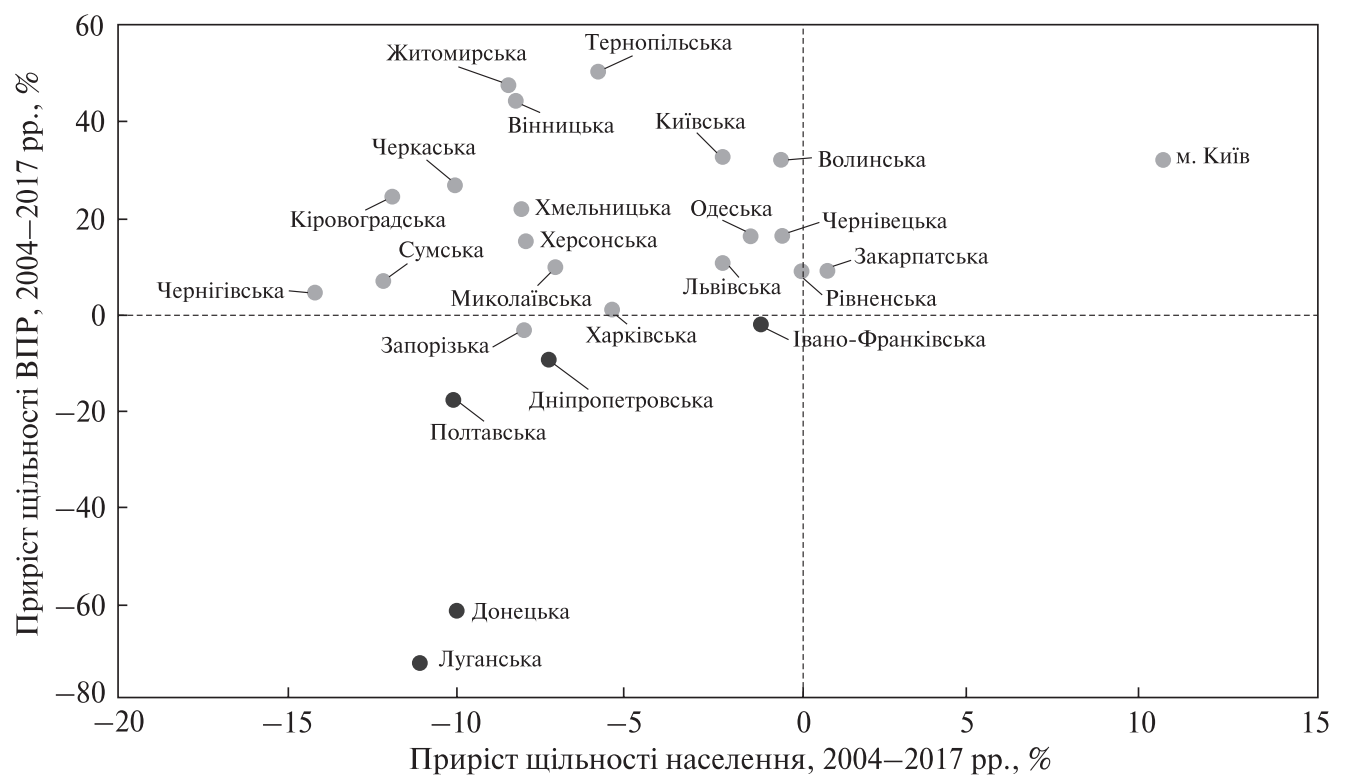

Рuc. 1. Дифузійна модель розвитку регіонів за період 2004-2017pp.*

* Дані за 2017 р. наведено без урахування тимчасово окупованої території Автономної Республіки Крим, м. Севастополь та частини тимчасово окупованих територій Донецької та Луганської областей.

Джерело: складено автором за даними Державної служби статистики України. 
Таблиия 1. Валовий регіональний продукт у розрахунку на одну особу у регіонах України за 2012-2017 роки у фактичних цінах, грн

\begin{tabular}{|c|c|c|c|c|c|c|}
\hline Регіон & 2012 & 2013 & 2014 & 2015 & 2016 & 2017 \\
\hline Україна & 32002 & 33473 & 36904 & 46413 & & \\
\hline АР Крим & 22675 & 23595 & $\ldots$ & $\ldots$ & $\ldots$ & $\ldots$ \\
\hline Вінницька & 20253 & 22303 & 27249 & 37270 & 46615 & 58384 \\
\hline Волинська & 19249 & 19817 & 23218 & 30387 & 34310 & 49987 \\
\hline Дніпропетровська & 44650 & 46333 & 53749 & 65897 & 75396 & 97137 \\
\hline Донецька & 38907 & 37830 & 27771 & 26864 & 32318 & 39411 \\
\hline Житомирська & 19551 & 20286 & 23678 & 30698 & 38520 & 49737 \\
\hline Закарпатська & 17088 & 17044 & 19170 & 22989 & 25727 & 34202 \\
\hline Запорізька & 30656 & 30526 & 37251 & 50609 & 59729 & 75306 \\
\hline Івано-Франківська & 23379 & 24022 & 27232 & 33170 & 37220 & 46312 \\
\hline Київська & 40483 & 39988 & 46058 & 60109 & 74216 & 90027 \\
\hline Кіровоградська & 22082 & 25533 & 29223 & 39356 & 47469 & 55183 \\
\hline Луганська & 25950 & 24514 & 14079 & 10778 & 14251 & 13883 \\
\hline Львівська & 24387 & 24937 & 28731 & 37338 & 45319 & 58221 \\
\hline Миколаївська & 24838 & 27355 & 30357 & 41501 & 50091 & 60549 \\
\hline Одеська & 27070 & 29118 & 31268 & 41682 & 50159 & 62701 \\
\hline Полтавська & 38424 & 39962 & 48040 & 66390 & 81145 & 106248 \\
\hline Рівненська & 18860 & 19003 & 24762 & 30350 & 33958 & 42038 \\
\hline Сумська & 21722 & 2351 & 26943 & 37170 & 41741 & 51419 \\
\hline Тернопільська & 16644 & 16819 & 20228 & 24963 & 29247 & 38593 \\
\hline Харківська & 29972 & 31128 & 35328 & 45816 & 51150 & 69489 \\
\hline Херсонська & 17910 & 19311 & 21725 & 30246 & 36585 & 45532 \\
\hline Хмельницька & 19920 & 20165 & 24662 & 31660 & 37881 & 49916 \\
\hline Черкаська & 24558 & 26168 & 30628 & 40759 & 48025 & 59697 \\
\hline Чернівецька & 14529 & 15154 & 16552 & 20338 & 23365 & 31509 \\
\hline Чернігівська & 22096 & 22603 & 26530 & 35196 & 41726 & 55198 \\
\hline м. Київ & 97429 & 109402 & 124163 & 155904 & 191736 & 238622 \\
\hline м. Севастополь & 25872 & 28765 & $\ldots$ & $\ldots$ & $\ldots$ & $\ldots$ \\
\hline
\end{tabular}

Джерело: за даними Державної служби статистики України.

негативний тренд. На межі критичних наслідків наявних тенденцій перебуває Харківська область з від’ємною динамікою щільності населення і майже відсутнім позитивним економічним зростанням. Певним чином може викликати здивування потрапляння до цієї групи Полтавської області, адже за підсумками 2017 року регіон має найвищий серед областей показник ВРП на одну особу - 106,2 тис. грн (табл. 1).

Водночас це відбувається на фоні скорочення економічної активності та чисельності населення в ньому. Поясненням може бути лише те, що останнім часом державні статистичні органи, характеризуючи економічні показники регіонів, ви- 
користовують лише фактичні ціни, що суттєво впливає на оцінку реального економічного становища в них.

Отже, сучасні тенденції регіонального розвитку характеризуються тривалою територіальною концентрацією економічної активності в деяких регіонах із одночасним скороченням промислового виробництва в інших - тих, які складали у минулому промислову основу країни. Це об'єктивний процес, який свідчить про структурні зміни на регіональному рівні, а також про відсутність реального впливу державної політики на скеровування цих змін у сприятливий для регіонального розвитку напрям. Подібне твердження вбачається важливим у період підготовки Кабінетом Міністрів України нової Державної стратегії регіонального розвитку (ДСРР), яка має визначати державну політику регіонального розвитку після 2020 року.

Нові концепції, які сьогодні впроваджують у розвинених країнах, зокрема гнучка спеціалізація (smart specialisation), або інші варіанти промислової політики, спонукають до розвитку інноваційних стратегій, що прискорюють регіональні структурні зміни, пов'язані із реформуванням економічної бази регіонів шляхом їх диверсифікації у нові сфери діяльності чи створення нових промислових секторів.

Така стратегічна орієнтація для регіональної інноваційної політики обгрунтована еволюційною економічною географією $(E E I)$ - новим напрямом регіональної науки, який досліджує структурні зміни в регіональних інноваційних системах (regional innovation system, RIS), суттєво серед суттєво відмінні у різних типах регіонів. Ці системи розрізняються за здатністю формувати нові напрями зростання з урахуванням відмінностей у ендогенному потенціалі регіонів і різниці у спроможності залучати екзогенні знання та ресурси для нових напрямів розвитку [10].

Відповідно, зміни у напрямах розвитку економіки треба розглядати з урахуванням різних типів регіональних інноваційних систем:

- шлях розвитку модернізації - вдосконалення наявних промислових сфер на основі нових технологій чи організаційних змін;

- розгалуження - диверсифікація наявних сфер промисловості;

- шлях імпортування - створення для регіону нової сфери промисловості;

- створення напряму розвитку, абсолютно нового для регіону.

Наукова література пропонує різноманітну класифікацію для визначення відмінностей між різними напрямами, як правило п'ятьма основними, регіонального розвитку (табл. 2).

Шлях модернізації чи оновлення належить до основних внутрішньорегіональних змін, які генерують спрямування розвитку промисловості на основі впровадження нових технологій (використання нових матеріалів чи технологій у традиційних галузях) чи запровадження проектної організації у креативних сферах.

Шлях розгалуження передбачає появу нових напрямів від наявних сфер промисловості і можливостей, які вже існують у регіоні. Він може з'явитися унаслідок різних дій, зокрема через диверсифікацію наявних компаній у нові виробничі сфери. У цьому випадку фірми поширюють діяльність у нових секторах шляхом перерозподілу активів і можливостей. Прикладом можуть бути екологічні технології виробництва, які відокремлюються від наявного інжинірингу, промисловості виробництва матеріалів та машинобудування у регіонах [12]. Шлях імпортування - це створення сфер промисловості, які є новими для регіону. Такі процеси можуть розпочатися із появою в регіоні іноземних компаній, кваліфікованих працівників із компетенціями, які відсутні серед зайнятих у регіоні, або завдяки віддаленому інноваційному партнерству. Внутрішнє інвестування іноземними компаніями часто вважають 
Таблиця 2. Напрями та механізми інноваційного розвитку регіонів

\begin{tabular}{|l|l|}
\hline \multicolumn{1}{|c|}{ Напрям розвитку } & \multicolumn{1}{c|}{ Механізм } \\
\hline Шлях розширення & $\begin{array}{l}\text { Розвиток наявних промислових сфер, який базується на інкремен- } \\
\text { тальному впровадженні інновацій по відомих, добре сформованих } \\
\text { технологічних траєкторіях }\end{array}$ \\
\hline $\begin{array}{l}\text { Шлях модернізації / } \\
\text { оновлення }\end{array}$ & $\begin{array}{l}\text { Основна зміна у новому напрямі промислового розвитку, упрова- } \\
\text { дження нових технологій чи організаційних інновацій }\end{array}$ \\
\hline Шлях розгалуження & $\begin{array}{l}\text { Розвиток нової промислової сфери на основі компетенцій та знань } \\
\text { у суміжних галузях }\end{array}$ \\
\hline Шлях імпортування & $\begin{array}{l}\text { Імплементація у промисловість регіону нової галузі, зокрема через } \\
\text { іноземне інвестування }\end{array}$ \\
\hline Шлях створення & $\begin{array}{l}\text { Поява та зростання нових сфер у промисловості на основі абсолютно } \\
\text { нових технологій і наукових відкриттів або як результат пошуку нових } \\
\text { бізнес-моделей, соціальних інновацій та стартапів }\end{array}$ \\
\hline
\end{tabular}

Джерело: складено за: [11].

ключовим фактором для шляху імпортування, якщо ці компанії створюють значну додану вартість та пов'язані із регіональною економікою, тобто мають зв'язки із регіональними суб'єктами.

Шлях створення нових сфер промисловості є найрадикальнішою формою змін. Це поява та зростання сфер, які базуються на нових технологічних та організаційних знаннях, що часто виникають у контексті наявних структур і напрямів розвитку технологій та інституційних механізмів. Як правило, шлях створення в нових сферах промисловості базується на активах, ресурсах чи компетенціях, що існують у регіоні, зокрема таких як якісна наукова база чи наявна якісно підготовлена робоча сила [13].

Так, зростання сектору «червоної» біотехнології у Відні базувалося на ендогенних компетенціях працівників медичних наукових установ а також на інвестуванні і знаннях іноземних компаній.

Вибір того чи іншого напряму розвитку залежить від типу регіональної інноваційної системи (RIS), сформованої в регіоні. $R I S$ можуть бути концептуалізовані як низка компаній, організацій та інституцій, які впливають на інноваційну поведінку та економічну діяльність на регіональному рівні [14]. Їх формують наявні промислові структури, технологічні можливості, організації, що генерують знання, інституції, які забезпечують підтримку та функціонування різноманітних мереж.

Аналіз наукової літератури щодо інноваційних регіональних систем дає змогу визначити використання для їх підтримки двох основних видів державної політики: один - спрямований на стимулювання діяльності суб'єктів і реалізацію інноваційних проектів компаній та інших стейкхолдерів. Він має на меті посилення інноваційного потенціалу і результативності деяких суб'єктів: великих компаній, середніх та малих підприємств, університетів, дослідницьких організацій. Інший - системно орієнтована стратегія, яка покращує функціонування регіональних інноваційних систем, усуваючи їхні слабкі сторони, сприяє нарощуванню місцевих та екзогенних потоків знань і адаптації організаційних та інституційних структур RIS. Системна політика зосереджена на покращенні результативності регіональної інноваційної системи як цілого. Вона передбачає кращу координацію, функціонування, внутрішню та зовнішню взаємодію груп суб'єктів усередині кластерів, зв'язків між університетами та компаніями, мобільної інфраструктури та схем перекваліфікації працівників [15]. 
Як зазначають дослідники, обидва підходи мають лише обмежений вплив на регіональні структурні зміни, коли застосовуються окремо. Водночас, їх комбінування дає змогу досягти позитивного ефекту у нових напрямах регіонального розвитку.

Цей аргумент випливає з факту, що новий сектор промисловості в регіоні чи основний напрям змін відбувається через два мікропроцеси: шляхом заснування фірм, які започатковують новий вид діяльності в регіоні, або шляхом упровадження нових видів діяльності на наявних підприємствах. Нові або наявні компанії є головними суб’єктами змін. Проте самі вони не здатні створити нові напрями зростання лише на власній основі, якщо дотримуватися підходу регіональних інноваційних систем. Подібні напрями з'являються у регіоні, коли:

• засновуються декілька функціонально взаємопов’язаних компаній;

- інвестори / компанії переконані у наявності попиту (наявного чи потенційного) на ринку;

- компанії знаходять необхідні фактори для започаткування діяльності в регіональній інноваційній системі й отримують доступ до виробничих та інформаційних мереж за межами регіону [16].

Основна ідея полягає в тому, що поява нових напрямів зростання перебуває не лише нового підприємництва та інноваційної активності; вона вимагає взаємопов’язаних компаній, які отримують вигоду від учасників та інституцій, що підтримують інноваційний процес.

Одним із найперспективніших сучасних підходів до формування стратегічних напрямів регіонального розвитку, який отримав активну стимуляційну підтримку в рамках нового програмного періоду політики регіонального розвитку в СС 20142020 рр., стало впровадження стратегій, які передбачають інтегрований розвиток, що спирається на концепцію територіальноспрямованого втручання з боку національних органів влади чи наднаціональних структур (place-based approaches) [17].

У загальному вигляді інтегровані територіальноспрямовані підходи визначають як:

- довготермінові стратегії розвитку з метою зменшення стійких проблем на територіях різного масштабу;

- надання пакету інтегрованих, територіально спрямованих публічних товарів і послуг, сформованого та імплементованого шляхом виявлення й поєднання місцевих переваг і знань через політичні інституції, а також налагодження зв'язків із іншими територіями;

- залучення системою багаторівневого управління на конкретну територію ресурсів, що відповідають умовам визначених для неї цілей вирішення проблем та інституцій і спрямовуються від вищих до нижчих територіальних рівнів влади [18].

Подібні підходи розглядають з точки зору декількох взаємопов’язаних вимірів, які можуть бути виокремлені у ході аналізування ряду виконаних останнім часом досліджень [ 19-22].

По-перше, географічний вимір, який визначає не просто структуризацію втручань - інвестиційних державних (європейських) інтервенцій на території - в рамках адміністративних меж, але й передбачає інтеграцію «специфічних місць» і забезпечує їхній зв’язок з іншими місцями. Тобто йдеться про функціональну територію, яка не має адміністративних меж, про покращення ефективності інтервенцій, що мають на меті сприяння розвитку. Інтеграція території логічно доповнюється застосуванням 
координаційних механізмів, які мають на меті покращити і гармонізувати інтервенції як у рамках, так і без врахування адміністративних меж [23].

Територіальна інтеграція може складатися з:

- стратегій які розробляють та погоджують декілька місцевих органів влади, що представляють частини функціональної території;

- імплементації стратегій у рамках спільних підходів місцевих органів влади в межах функціональної території;

• заснування нових організацій, які об’єднують декілька місцевих органів влади функціональної території чи делегування певних повноважень наявним подібним організаціям.

Практика використання інтегрованих стратегічних підходів до розвитку територій у країнах ЄС свідчить, що в програмний період 2014-2020 рр. стратегії сталого розвитку запроваджували як на функціональних урбанізованих територіях, так і в адміністративних межах міст, одного або декількох адміністративних районів. Половина стратегій стосується певних адміністративно-територіальних одиниць, третина впроваджується на територіях, що охоплюють кілька суміжних адміністративно-територіальних одиниць, масштаб може бути різним. Зокрема, у Фінляндії стратегія охоплює шість міст, створюючи мережу, базовану на різноманітних формах кооперації. У Бельгії ряд стратегій стосується розвитку цілої провінції, яку не можна розглядати як функціональну територію. У Болгарії стратегія стосується міст у їхніх адміністративних межах, але заходи з імплементації стратегії поширюються на так звані зони інтервенції, тобто зони з публічними функціями, зони соціальних інтервенцій і зони із потенціалом економічного розвитку.

Подібна цільова спрямованість має місце у низці стратегій, що стосуються функціональної урбанізованої території. Так, кожна з дев'яти стратегій у Франції стосується функціональної урбанізованої території, сформованої об'єднаними в асоціацію муніципалітетами. При цьому всередині території заходи імплементуються у районах, визнаних пріоритетними у рамках національної політики урбанізації.

У цілому це стосується третини стратегій, запроваджених у країнах $\mathrm{CC}$ : хоча стратегії розроблені для великих територій, вони націлені на конкретні місця чи зони. Непов'язані з розвитком урбанізованих територій стратегії охоплюють переважно невеликі центри сільських територій. Вони розроблені для певних воєводств у Польщі, для прибережних, острівних, гірських, територій, а також територій природних заповідників країн $Є C$.

Важливою особливістю багатьох стратегій у Франції, Італії, Португалії, Румунії, Федеративній Республіці Німеччини є те, що вони мають на меті зменшення диспропорцій між урбанізованими і сільськими територіями у краще інтегрованих підходах, які передбачають концентрацію інтервенцій у взаємопов'язаних пріоритетах для посилення зв'язку між урбанізованими та сільськими територіями.

По-друге, інтегрований територіально-спрямований підхід має на меті підвищити інтеграцію інтервенцій. Цей вимір передбачає інтеграцію державних політик у різних секторах економіки та інтервенцій у намаганні покращити їх ефективність і запровадити краще інтегрований підхід до регіонального / місцевого розвитку. Синергія може виникнути у випадку комбінування джерел фінансування цілеспрямованих місцевих ініціатив. Цей вимір може охоплювати:

- інтеграцію стратегічних цілей від декількох місцевих стратегій;

- формування пріоритетів інвестування від декількох тематичних цілей;

- використання різноманітних джерел фінансування; 
- інтеграцію внутрішніх (місцевих, регіональних) та державних (європейських) цільових пріоритетів.

Аналіз формування цілей у рамках стратегій сталого розвитку урбанізованих територій засвідчує, що основними є соціальне включення (social inclusion), збереження навколишнього середовища, забезпечення транспортними послугами, стимулювання низьковуглецевої економіки та економічне зростання. Як правило, цілі у стратегіях визначають виходячи із адекватної діагностики викликів, ідентифікованих на певних територіях. Дослідження свідчать, що рівень інтегрованості заходів для кожної стратегії в різних країнах суттєво варіює. Так, стратегії в Хорватії, Кіпрі, Чехії, Греції, Литві та Польщі визначають відносно значну кількість інвестиційних пріоритетів у кожній стратегії, у той час як стратегії в Австрії, Бельгії, Естонії, ФРН, Ірландії, Мальті, Румунії, Словенії та Швеції мають порівняно незначну кількість таких пріоритетів. Більше того, у Хорватії, Франції, Греції, Польщі діапазон інвестиційних пріоритетів суттєво варіює. Зокрема, у Польщі найменша кількість подібних пріоритетів у стратегіях - п’ять, а найбільша - тридцять один. Більшість національних експертів із країн ЄС відмічають, що стратегії розвитку територій у 53-79 \% випадків сповідують інтегрований міжсекторний підхід [24].

Третій вимір стосується інтеграції знань, тобто використання інтегрованого підходу, який змінює практику і спроможність постачати й імплементувати територіальну політику розвитку у територіальні інституційні структури. Так, інтеграція відбувається через:

- посилення стратегічного мислення та запровадження пріоритетності визначення дій і концентрацію на них ресурсів на місцевому рівні;

- забезпечення місцевої / регіональної спільноти можливостями імплементації соціальних та економічних ініціатив, запровадження партисипативного управління у стратегічному розвитку;

- стимулювання та розвиток інноваційних підходів.

Даний вимір ідентифікується в рамках територіально спрямованого підходу у процесі обгрунтування доцільності використання для розвитку місцевих знань, які підтримуються ідеями та фінансуванням із центрального територіального рівня. При цьому спроможності забезпечення можливостей місцевої / регіональної спільноти розрізняються застосуванням різних підходів - «зверху згори донизу» та «знизу вгору». Елементи першого підходу обумовлені способом імплементації стратегій, коли вони фінансуються із Європейських фондів і мають відповідати вимогам, які встановлює Європейська Комісія чи національний уряд країни ЄС. Наявність підходів «знизу вгору» обумовлена значною підтримкою розвитку стратегічних процесів на функціональних територіях місцевими органами влади.

Участь різних суб’єктів у різних стадіях стратегічного процесу забезпечується залученням до розроблення стратегій органів влади різних територіальних рівнів - від муніципального до національного. У ряді випадків відзначається активна участь на даному етапі представників наукових та експертних кіл, що дає змогу гарантувати загальне усвідомлення специфічності території запровадження стратегії та ефективне партнерство в іії імплементації. Подібні широкі групи учасників стратегічного процесу, які складаються із представників економічного і соціального партнерства, громадських організацій, організацій приватного сектору, представників населення, можуть набудувати різних форм: консультативні ради, ради партнерства, групи впровадження, ради програмування, робочі групи тощо. 
Четвертий - управлінський вимір (a governance dimension) передбачає участь політичних інституцій і визначає, до яких вертикальних і горизонтальних відносин підвищується зв’язок між партнерами та яким чином розподіляється відповідальність для запровадження інтегрованого підходу до регіонального / місцевого розвитку. Інтеграція території логічно доповнюється запровадженням механізму координації, який має покращити і гармонізувати інтервенції. До цього типу багаторівневої інтеграції відносять:

- розподіл та делегування відповідальності за імплементацію та менеджмент фінансових капітальних інтервенцій (у рамках ЄC - Европейського структурного та інвестиційного фонду (European Structural and Investment Funds, ESIF) на місцевий рівень влади;

- створення нових інституцій чи інтеграція нових функцій щодо імплементації стратегій інтегрованого розвитку та політик, які посилюють вертикальне та горизонтальне багаторівневе партнерство.

Аналіз стратегій розвитку адміністративно-територіальних одиниць та їх об'єднань допомагає ідентифікувати ключові тенденції. У 60 \% випадків відповідальність за імплементацію стратегій покладена на місцеві органи влади чи на асоціації таких органів. У 20 \% випадків відповідальність за місцеві стратегій розвитку розподіляється між різними територіальними рівнями влади.

Основна відмінність може бути визначена між випадками, коли органи державної влади країни домінують у формуванні та імплементації місцевих стратегій, а делегування на місцевий та регіональний рівень обмежене, і випадками, коли значний рівень відповідальності делегований на місцевий та регіональний рівні влади.

Як головні чинники подібної відмінності дослідники розглядають часткове та значне делегування [24]:

1. Часткове делегування. Домінування центральної влади обумовлено обмеженістю спроможностей місцевих / регіональних органів влади здійснити загальну імплементацію процесу. У той же час, існує постійна взаємодія між різними рівнями влади для координації та кооперації різних партнерів у рамках інтегрованого інвестиційного процесу. На місцеву владу у цих випадках покладається зобов'язання підготовки проектних пропозицій, які відбирають не за конкурсною процедурою. Жодна заявка на здійснення інтегрованих інвестицій не може бути здійснена без перевірки на центральному рівні. Зокрема, у Латвії таке повноваження закріплено за Міністерством фінансів. Інший випадок подібного обмеження делегування місцевим органам відповідальності за реалізацію інтегрованих процесів обумовлено вимогами використання європейських фондів, задіяних у даний програмний період Політики Єднання.

2. Значне делегування. Домінування місцевих органів влади має місце у випадках, коли місцеві органи мають спроможність чи значний досвід імплементації проектів Європейського Союзу або сповідують проактивний підхід. Як приклад, місцеві органи влади агломерації Walbrzych у Польщі - єдиної, яка має відповідальність за впровадження інтегрованої інвестиційної стратегії. Усі інші подібні стратегії залежать від ступеня підтримки регіональних органів влади, які мають формально та за змістом оцінювати інвестиційні проекти, підписувати контракти з бенефіціарами та здійснювати фінансовий контроль.

Незважаючи на суттєві виклики, які виникають унаслідок делегування повної відповідальності за реалізацію інтегрованих стратегій, для суб’єктів агломерації 
важливо безпосередньо керувати ними для формування місцевих можливостей та забезпечення ухвалення рішень на місцевому рівні.

Управління механізмами моніторингу та оцінювання прогресу інтегрованих територіально спрямованих стратегій істотно різні. У цей процес залучено значну кількість територіальних рівнів влади та організацій. Як правило, національний і регіональний рівні відіграють у цьому процесі вагомішу роль. Для ряду випадків можливе розрізнення між завданнями зі збору даних, моніторингу та звітування, яке виконується місцевими органами влади, й оцінюванням, відповідальність за яке покладена на регіональні та національні рівні влади.

Означені виміри спільно стимулюють та сприяють запровадженню інтегрованого територіально спрямованого підходу у 2014-2020 pp. у рамках Європейського Союзу. Відмінностями від попереднього програмного періоду є те, що:

- загальне фінансування інтегрованого територіально спрямованого підходу збільшено. Відповідно до запровадженого механізму територіального розподілу в Операційних Програмах майже 9 \% бюджету політики єднання СС (31 млрд євро) спрямовано через різноманітні територіальні канали;

- запроваджено регуляторні вимоги для імплементації інтегрованого територіально спрямованого підходу в містах;

- інтегрованому підходу приділено посилену увагу Європейської Комісії;

- на програмному рівні вимагається більше інформації щодо запровадження інтегрованого територіально спрямованого підходу;

• більше уваги приділено поширенню знань серед місцевих органів влади щодо застосування нових підходів ЄС у територіальному розвитку.

Основні висновки із упровадження викладених вище підходів до застосування інтегрованих стратегій розвитку дають експертам ЄС підстави стверджувати, що:

- стратегії розвитку, що складаються із кількох пов’язаних і взаємно сприятливих дій і втручань на територіях розвитку дають відчутніші результати;

- стратегічні підходи до стимулювання економічного зростання, що базуються на твердих позиціях грунтовного діагнозу, в цілому є успішнішими;

- критичним для отримання позитивних результатів застосування інтегрованої стратегії є чітке і системне уявлення про стан економічного і соціального розвитку території, де вона буде імплементована [24].

У цьому контексті повчальний приклад удосконалення відповідних механізмів державного регулювання демонструє уряд Польщі, який модернізує систему стратегічного управління регіональним та місцевим розвитком. Про це свідчить чотирирічна Стратегія Відповідального Розвитку (The Strategy for Responsible Development, $S R D)$, що визначає напрям розвитку Польщі на період до 2020 року. Її імплементація здійснюється шляхом упровадження дев'яти модернізованих секторальних інтегрованих стратегій, базованих на стратегічних програмах. Ціль $S R D-$ створити умови для формування високих доходів населення та кращої якості життя, забезпечуючи одночасно конкурентоздатність національної економіки [25]. Три основні завдання в державній політиці визначено ключовими для підтримки даної цілі. Польща прагне створити законодавчі, інституційні та інвестиційні умови, які забезпечать:

- стале економічне зростання, яке базується на знаннях, інформації та організаційних перевагах;

- соціально чутливий і територіально сталий розвиток;

- ефективну державу та економічні інститути, які роблять внесок у зростання, а також соціальну та економічну інклюзію (рис. 2). 


\begin{tabular}{|c|c|c|}
\hline Ціль 1 & Ціль 2 & Ціль 3 \\
\hline $\begin{array}{l}\text { Стале економічне зростання } \\
\text { на основі наявних та нових } \\
\text { переваг: } \\
\text { • реіндустріалізація на осно- } \\
\text { ві повнішого використання } \\
\text { внутрішніх ресурсів країни; } \\
\text { • інноваційний розвиток } \\
\text { бізнесу, стимулювання розви- } \\
\text { тку нових технічних } \\
\text { та організаційних рішень } \\
\text { на основі власних ресурсів } \\
\text { підприємств; } \\
\text { • малі та середні підприєм- } \\
\text { ства-капітал для зростання; } \\
\text { • мобілізація різноманітних } \\
\text { джерел капіталу для розвитку; } \\
\text { • експансія польських } \\
\text { підприємств на зовнішніх } \\
\text { ринках }\end{array}$ & $\begin{array}{l}\text { Соціально та територіально } \\
\text { чутливе зростання: } \\
\text { • соціальне єднання; } \\
\text { • територіально сталий роз- } \\
\text { виток: переваги від економіч- } \\
\text { ного розвитку країни мають } \\
\text { бути доступними } \\
\text { для усіх жителів, незалежно } \\
\text { від місцезнаходження }\end{array}$ & $\begin{array}{l}\text { Ефективна держава та еконо- } \\
\text { мічні інститути для зростан- } \\
\text { ня, а також для соціального } \\
\text { та економічного охоплення: } \\
\text { • спрощення регулювання } \\
\text { та підвищення якості законо- } \\
\text { давчих актів; } \\
\text { • інститути, спрямовані } \\
\text { на стратегічний розвиток, } \\
\text { координацію його складових; } \\
\text { • використання в державному } \\
\text { управлінні цифрових техно- } \\
\text { логій; } \\
\text { • стабільні, ефективні та сталі } \\
\text { публічні фінанси; } \\
\text { • координація використання } \\
\text { коштів фондів ЄС з метою } \\
\text { підвищення рівня створення } \\
\text { доданої вартості у ході реалі- } \\
\text { зації проектів }\end{array}$ \\
\hline
\end{tabular}

Рис. 2. Ключові цілі Стратегії відповідального розвитку Польщі

Джерело: складено за [26].

Нова стратегія визначає, що рушієм недавнього бурхливого економічного зростання в Польщі в основному було підвищення добробуту урбанізованих агломерацій, у той же час більшість невеликих міст і сільських територій не брали в цьому адекватної участі та не отримали відповідної вигоди. Бідність і соціальна відчуженість периферійних територій стали наслідками цього процесу, і таку тенденцію має подолати затверджена урядом Стратегія Відповідального Розвитку.

Основними елементами нового, інтегрованого підходу, є:

- підготовка документів економічного, соціального та просторового характеру на уніфікованій основі;

- удосконалений (на основі регулювання) механізм погодження документів різних територіальних рівнів, що формує стратегічну програмну систему;

- стратегічний державний інвестиційний механізм, який враховує інтереси усіх залучених суб'єктів (місцеві органи влади, спільноти, підприємства) у рамках територіального контракту;

• інтеграція інтервенцій політики розвитку, що здійснюється різними суб'єктами національного, регіонального та місцевого рівнів із урахуванням принципу субсидіарності;

- визначення територій стратегічного втручання на національному, регіональному чи місцевому рівні.

Пропоновані зміни повинні покращити багаторівневе управління, забезпечити чітко означені цілі та завдання розвитку кожного територіального рівня одночасно із механізмом взаємодії через територіальні контракти. Інтегровані стратегії, які враховують широкий спектр сфер політики, повинні стимулювати компліментарність і усе більшу пов'язаність інвестицій, зокрема координацію інвестицій у розвиток транспортної мережі із інвестиціями у нові навчальні заклади чи медичні та рекреаційні 
центри на територіях динамічного зростаннях; об’єднання послуг та їх постачання на території, де скорочується чисельність населення.

Подібний підхід вимагає відповідних ефективних відносин взаємодії між центральними органами виконавчої влади у здійсненні політики в різних секторах (фактично, йдеться про створення складових стратегічної маневреності). Крім того, важливим є усвідомлення, що стратегії інтегрованого розвитку - не тільки інструмент удосконалення державного планування; вони слугують інструментом комунікації між державними органами влади та населенням для активізації діалогу та визначення напрямів подальшого розвитку. У формуванні масштабу та характеру цієї інтегрованої основи на наступні роки уряд Польщі розглядатиме роль таких стратегій як обов'язкових документів і визначатиме, яким чином вони можуть бути використані як інструмент управління всередині апарату органів влади для стимулювання спільної діяльності різних його підрозділів для ухвалення рішень щодо спрямування державних інвестицій і залучення фізичних та юридичних осіб до процесів розвитку.

Важливим є і те, що Стратегія відповідального розвитку визначає ряд територій країни цільовими для спеціальної підтримки (табл. 3). Передбачено, що цільова територіальна підтримка продовжуватиметься в рамках чинних програм, наприклад, низка заходів для територій на сході країни. Нові ініціативи, зокрема стратегічні проекти $S R D$ - Пакт для сільських територій, пропонують координовані заходи сільського розвитку з метою покращення цільової підтримки шляхом використання національних фондів і фондів СС, узгодженої із думкою численних учасників - експертів, центральних органів влади, органів влади воєводств, недержавних організацій, дослідницьких установ, сільськогосподарських суб'єктів. Із залученням різних груп інтересів на ранній стадії процесу роботи над документом пропонуватиметься ширший спектр проектів, спрямованих на розвиток пріоритетних сфер: розвиток підприємництва, технічну та соціальну інфраструктуру, публічні послуги, захист навколишнього середовища, сільськогосподарські ринки тощо.

Таблиия 3. Заходи Стратегії відповідального розвитку щодо окремих територій Польщі

\begin{tabular}{|l|l|}
\hline \multicolumn{1}{|c|}{ Визначена територія } & \multicolumn{1}{|c|}{ Заходи стратегічного впливу } \\
\hline Східна Польща & $\begin{array}{l}\text { Пакет заходів для Східної Польщі - посилення координації ін- } \\
\text { струментів впливу на розвиток; міжрегіональні програми } \\
\text { для відсталих регіонів }\end{array}$ \\
\hline Сілезія & $\begin{array}{l}\text { Програми підтримки сприятливого клімату для залучення інвес- } \\
\text { тицій і сприяння структурних змін }\end{array}$ \\
\hline $\begin{array}{l}\text { Середні міста, що втрача- } \\
\text { ють соціальні та еконо- } \\
\text { мічні функції }\end{array}$ & $\begin{array}{l}\text { Програми просторової інтеграції таких міст із територіями висо- } \\
\text { кої динаміки розвитку }\end{array}$ \\
\hline $\begin{array}{l}\text { Території із загрозою пер- } \\
\text { манентної маргіналізації }\end{array}$ & $\begin{array}{l}\text { Програми цільової інвестиційної підтримки на диверсифікованй } \\
\text { основі }\end{array}$ \\
\hline Сільські території & $\begin{array}{l}\text { Пакт для сільських територій, який підтримує розвиток сільських } \\
\text { громад }\end{array}$ \\
\hline Регіональні агломерації & $\begin{array}{l}\text { Програми підтримки самоврядування із відновлення } \\
\text { життєдіяльності, ініціативи з урбанізації, інтегровані територіаль- } \\
\text { ні інвестиції }\end{array}$ \\
\hline
\end{tabular}

Джерело: [25]. 
Подібні ініціативи - можливість для фундаментальних змін у майбутньому і конкретизації зусиль з розширення міжсекторальної координації на національному рівні, яка є альтернативою чинним неефективним механізмам територіального розвитку у Польщі.

3 урахуванням проблем стратегічного управління розвитком в українському суспільстві, дослідження результативності таких ініціатив сусідньої держави видається доцільним.

Висновок. Підсумовуючи викладене, варто виокремити ряд пропозицій, які можуть удосконалити майбутню державну політику регіонального розвитку України.

1. Надзвичайно важливим видається запровадження інтегрованих підходів до розвитку територій субнаціонального рівня. В умовах динамічного скорочення жителів у населених пунктах сільської місцевості, а також малих міст, концентрації товарів, послуг, робочої сили, знань, фінансових ресурсів у великих містах, дані підходи залишаються чи не єдиним шляхом забезпечення всієї території країни базовими публічними послугами для жителів незалежно від їх місцезнаходження.

2. Успіх упровадження державної політики регіонального розвитку в країні значною мірою залежить від формування системи багаторівневого управління. Її незавершеність суттєво скорочує можливості стратегічного розвитку на регіональному (обласному та районному) рівні. Обмеженість у повноваженнях та ресурсах, що $є$ ключовим чинником для повноцінного багаторівневого управління, скорочує зацікавленість місцевих органів влади та місцевого самоврядування ухвалювати стратегічні рішення, пов'язані із регіональним / місцевим розвитком та нести політичну відповідальність за їх реалізацію перед своїми виборцями.

3. У стратегічному вимірі держава має стимулювати формування регіональних (міжрегіональних - на інтегрованій основі) інноваційних систем, які сприятимуть відродженню промисловості в регіонах на нових структурних засадах, що є запорукою якісного підвищення добробуту жителів громад.

\section{ЛІТЕРАТУРА}

1. Мінрегіон починає розробку Державної стратегії регіонального розвитку України на період до 2027 року [Електронний ресурс] - Режим доступу: http://invest.kharkiv.ua/index.php?route= information/ (дата звернення: 15.05.2019).

2. Про затвердження Державної стратегії регіонального розвитку на період до 2020 року: Постанова Кабінету Міністрів України від 06.08.2014 № 385 [Електронний ресурс]. - Режим доступу: https://www.kmu.gov.ua/npas/247566248 (дата звернення: 15.05.2019).

3. Бойко А. Планування регіонального розвитку в Україні // Вісник КНТЕУ. - 2017. - № 1. C.19-35.

4. Романюк C.A. Теорія та практика стратегічного управління: Нац. акад. держ. управл. при Президентові України. - Київ, 2019. - 234 с.

5. Підготовка проектів на ДФРР. Центр розвитку місцевого самоврядування. Дніпропетровський відокремлений підрозділ. 2018 [Електронний ресурс]. - Режим доступу: http://gdc.org.ua/ sites/default/files/library/3._pidgotovka_proektiv_na_dfrr-ilovepdf-compressed.pdf (дата звернення: 02.04.2019).

6. Беззубко Б., Беззубко Ю. Проблеми сучасного етапу стратегічного планування розвитку територіальних громад у Донецькій області // Економічний вісник Донбасу. - 2018. - № 2 (52). C. $17-20$.

7. Підтримання темпу процесу децентралізації в Україні. ОЕСР. - Париж, - 2018. - https://doi. org/10.1787/9789264301481-uk 
8. Романюк С.А. Розвиток регіонів у відкритій економіці:теорія, політика, практика: Нац. акад. держ. управл. при Президентові України. - Київ, 2013. - 408 с.

9. Романюк C.A. Регіональний розвиток і децентралізація: теоретичні і практичні аспекти // Регіональна економіка. - 2016. - № 3 (81). - С. 10-18.

10. Isaksen A., Trippl M. Path Development in Different Regional Innovation Systems. - Innovation Drivers and Regional Innovation Strategies, Parrilli M.D., Fitjar R.D. and Rodriguez-Pose A. (Eds.) Routledge. - 2016. - P. 66-84.

11. Isaksen, $A$. Industrial Development in Thin Regions: Trapped in Path Extension // Journal of Economic Geography. - 2015. - № 15 (3). - P. 585-600.

12. Tödtling F. Trippl M. Transformation of regional innovation systems: From old leagacies to new development paths // Reframing Regional Development, Cooke P (Ed.). - London: Routledge, 2013. - P. 297-317.

13. Martin R. Roepke Lecture in Economic Geography - Rethinking Regional Path Dependence: Beyound Lock-in to Evolution // Economic Geography. - 2010 - № 86 (1).- P. 1-27.

14. Asheim B.T. Gertler M. The geography of innovation: regional innovation systems, // The Oxford Handbook of Innovation / J. Fagerberg, D.C. Mowery and R. Nelson (Eds). - Oxford, UK: Oxford University Press, 2005. - P. 291-317.

15. Asheim B.T., Isaken I., Nauwelaers C., Tödtling F. (Eds) Regional Innovation Policy for Small-Medium Enterprises. - Cheltenham: Edward Elgar, 2003.- 264 p.

16. Binz C., Truffer L., \& Coenen L. Path creation as a process of resource alignment and anchoring: Industry formation for on-site water recycling in Beijing // Economic Geography. - 2016.№ 92 (2). - P. 72-200. - https://doi.org/10.1080/00130095.2015.1103177

17. Van der Zwet A., Mendez C. Towards a Europe of the Localities? Integrated place-based approaches in Cohesion policy in 2014-20 and beyond // Challenges for the New Cohesion Policy 2014-2020, $2^{\text {nd }}$ Joint EU Cohesion Policy Conference. (Riga, 4-6 February). - 2015 [Електронний ресурс]. - Peжим доступу: - https://strathprints.strath.ac.uk/52705/1/van_der_Zwet_CNCP_2015_Towards_a_ Europe_of_the_localities.pdf (дата звернення: 12.06.2019).

18. Zaucha J., Ś Swiatek D. Place-Based Territorially Sensitive and Integrated Approach.- Warsaw, 2013.

19. My Region, My Europe, Our Future: The seventh Report on economic, social and territorial cohesion. - European Commission. - Luxembourg: Publications Office of the European Union, 2017. [Електронний ресурс]. - Режим доступу: https://eur-lex.europa.eu/legal-content/FR/TXT/?qid= 1508317360588\&uri=CELEX:52017SC0330 (дата звернення: 15.05.2019).

20. Iammarino S., Rodriguez-Pose A., Storper M. Why Regional Development Matters for Europe's Economic Future: Working Papers WP 07/2017. / European Commission. - Luxembourg, 2017 [Електронний peсурс]. - Режим доступу: https://ec.europa.eu/regional_policy/sources/docgener/work/201707_ regional_development_matters.pdf (дата звернення: 15.05.2019).

21. Bachtler J., Oliviera M.J., Woster P., Zuber P. Towards Cohesion Policy 4.0: Structural Transformation and Inclusive Growth / Regional Studies Association Europe. - Brussels, 2017 [Електронний pecypc]. Режим доступу: https://3ftfah3bhjub3knerv1hneul-wpengine.netdna-ssl.com/wp-content/ uploads/2018/08/RSA_Report_Web_22-6-17.pdf (дата звернення: 12.06.2019).

22. Competitiveness in low-income and low-growth regions: the lagging regions report. / European Commission. - Brussels, 2017 [Електронний pecypc]. - Режим доступу: https://ec.europa.eu/ regional_policy/sources/docgener/studies/pdf/lagging_regions\%20report_en.pdf (дата звернення: 05.05.2019).

23. Report on New Territorial Development Tools in Cohesion Policy 2014-2020: Integrated Territorial Investment (ITI) and Community-Led Local Development (CLLD) / European Parliament. Brussels, 2016 - 21 р. [Електронний ресурс]. - Режим доступу: http://www.europarl.europa.eu/doceo/ document/A-8-2016-0032_EN. pdf (дата звернення: 12.06.2019).

24. Van der Zwet A., Ferry M., McMaster I. Integrated territorial and urban strategies: how are ESIF adding value in 2014-2020? / European Commission. - Brussels, 2017. - 152 р. [Електронний ресурс]. - Режим доступу: https://ec.europa.eu/regional_policy/sources/docgener/studies/pdf/ integrated_strategies/integrated_strategies_en.pdf (дата звернення: 05.05.2019).

25. Strategy for Responsible Development-Delegate. Government of Poland [Електронний ресурс] - Режим доступу: https://www.delegate.com/.../2017/.../Poland\%20-\%20Pawel (дата звернення: 05.05.2019). 
26. Decentralization and multi-level governance in Poland. Ensuring coherence between national and subnational development strategies/policies. - Режим доступу: https://www.oecd.org/regional/regionalpolicy/Decentralisation-and-multi-level-governance-in-Poland.pdf (дата звернення 05.05.2019).

\section{REFERENCES}

1. Minrehion pochynaye rozrobku Derzhavnoyi stratehiyi rehional'noho rozvytku Ukrayiny na period do 2027 roku [The Ministry of Regional Development begins to develop the State Strategy for Regional Development of Ukraine for the period until 2027]. (n.d.). Retrieved from: http//invest.kharkiv.ua/index.php?route= information [in Ukrainian].

2. Postanova Kabinetu Ministriv Ukrayiny vid 6 serpnya 2014 r. № 385 «Pro zatverdzhennya Derzhavnoyi stratehiyi rehional'noho roku na period do 2020 roku» [Resolution of the Cabinet of Ministers of Ukraine dated 06.08.2014 № 385 «On approval of the State strategy of the regional year for the period up to 2020»]. (2014, 6 August). Retrieved from https://www.kmu.gov.ua/npas/247566248 [in Ukrainian].

3. Boyko, A. (2017). Planuvannya rehional'noho rozvytku v Ukrayini [Planning for regional development in Ukraine]. Visnyk KNTEU - KNTEU Bulletin, 1, 19-35 [in Ukrainian].

4. Romanyuk, S.A. (2019). Teoriya ta praktyka stratehichnoho upravlinnya [The theory and practice of strategic management]. Kyiv: NADU [in Ukrainian].

5. Pidhotovka proektiv na DFRR. Tsentr rozvytku mistsevoho samovryaduvannya. Dnipropetrovs'kyy vidokremlenyy pidrozdil [Preparation of projects for the SFRD. Center for Local Self-Government Development. Dnepropetrovsk detached unit]. (2018). Retrieved from http://lgdc.org.ua/sites/default/files/library/3. pidgotovka_proektiv_na_dfrr-ilovepdf-compressed.pdf [in Ukrainian]

6. Bezzubko, B., \& Bezzubko, Yu. (2018). Problemy suchasnoho etapu stratehichnoho planuvannya rozvytku terytorial'nykh hromad u Donets'kiy oblasti [Problems of the current stage of strategic planning of development of territorial communities in Donetsk region]. Ekonomichnyy visnyk Donbasu - Economic Bulletin of Donbass, 2(52), 17-20 [in Ukrainian].

7. Pidtrymannya tempu protsesu detsentralizatsiyi $v$ Ukrayini [Maintaining the pace of decentralization in Ukraine]. (2018). OECD. Paryzh: OESR. - http: dx.doi.org/10.1787/9789264301481-uk [in Ukrainian].

8. Romanyuk, S.A. (2013). Rozvytok rehioniv u vidkrytiy ekonomitsi: teoriya, polityka, praktyka [Development is in the open economic aspects: theory, politics, practice]. Kyiv: NADU pry Prezydentovi Ukrayiny [in Ukrainian].

9. Romanyuk, S.A. (2016). Rehional'nyy rozvytok i detsentralizatsiya: teoretychni i praktychni aspekty [Regional Development and Decentralization: Theoretical and Practical Aspects]. Rehional'na ekonomika - Regional Economics, 3 (81), 10-18 [in Ukrainian].

10. Isaksen, A., \& Trippl, M. (2016). Path Development in Different Regional Innovation Systems. Innovation Drivers and Regional Innovation Strategies. M.D. Parrilli, R.D. Fitjar \& A. Rodriguez-Pose (Eds.). Routledge: New York and London.

11. Isaksen, A. (2015). Industrial Development in Thin Regions: Trapped in Path Extension. Journal of Economic Geography, 15 (3), 585-600.

12. Tödtling, F. \& Trippl, M. (2013). Transformation of regional innovation systems: From old leagacies to new development paths. Reframing Regional Development. P. Cooke (Ed.). London: Routledge.

13. Martin, R. (2010). Roepke Lecture in Economic Geography - Rethinking Regional Path Dependence: Beyound Lock-in to Evolution. Economic Geography, 86 (1), 1-27.

14. Asheim, B.T. \& Gertler, M. (2005). The geography of innovation: regional innovation systems. The Oxford Handbook of Innovation Oxford. J. Fagerberg, D.C. Mowery \& R. Nelson (Eds.). UK: Oxford University Press.

15. Asheim, B.T., Isaken, I., Nauwelaers, C., \& Tödtling, F. (Eds). (2003). Regional. Innovation Policy for Small-Medium Enterprises. Cheltenham: Edward Elgar.

16. Binz, C., Truffer, L., \& Coenen, L. (2016). Path creation as a process of resource alignment and anchoring: Industry formation for on-site water recycling in Beijing. Economic Geography, 92 (2), 72-200. - doi:10.1080/00130095.2015.1103177.

17. Van der Zwet, A. \& Mendez C . (2015). Towards a Europe of the Localities? Integrated place-based approaches in Cohesion policy in 2014-20 and beyond. Proceedings from Challenges for the New Cohesion Policy 2014-2020: $2^{\text {nd }}$ Joint EU Cohesion Policy Conference (2-4 February 2015). Riga. Retrieved from https://strathprints.strath.ac.uk/52705/1/van_der_Zwet_CNCP_2015_Towards_a_Europe_of_the_ localities.pdf 
18. Zaucha, J. \& Świątek, D. (2013). Place-Based Territorially Sensitive and Integrated Approach. Warsaw.

19. My Region, My Europe, Our Future: The seventh Report on economic, social and territorial cohesion (2017). European Commission. Luxembourg: Publications Office of the European Union Retrieved from https://eur-lex.europa.eu/legal-content/FR/TXT/?qid=1508317360588\&uri= CELEX:52017SC0330

20. Iammarino, S., Rodriguez-Pose, A., \& Storper, M. (2017). Why Regional Development Matters for Europe's Economic Future. Working Papers, 07. European Commission. Luxembourg. Retyrieved from https://ec.europa.eu/regional_policy/sources/docgener/work/201707_regional_development_matters. pdf

21. Bachtler, J., Oliviera, M.J., Woster, P., \& Zuber, P. (2017). Towards Cohesion Policy 4.0: Structural Transformation and Inclusive Growth. Regional Studies Association Europe. Brussels. Retrieved from https://3ftfah3bhjub3knerv1hneul-wpengine.netdna-ssl.com/wp-content/uploads/2018/08/ RSA_Report_Web_22-6-17.pdf

22. Competitiveness in low-income and low-growth regions: the lagging regions report (2017). European Commission. Brussels. Retrieved from https://ec.europa.eu/regional_policy/sources/docgener/studies/pdf/ lagging_regions\%20report_en.pdf

23. Report on New Territorial Development Tools in Cohesion Policy 2014-2020: Integrated Territorial Investment (ITI) and Community-Led Local Development (CLLD) (2016). European Parliament. Brussels. Retrieved from http://www.europarl.europa.eu/doceo/document/A-8-2016-0032_EN. pdf

24. Van der Zwet, A., Ferry, M., \& McMaster, I. (2017). Integrated territorial and urban strategies: how are ESIF adding value in 2014-2020? European Commission. Brussels. Retrieved from https://ec.europa. eu/regional_policy/sources/docgener/studies/pdf/integrated_strategies/integrated_strategies_en.pdf

25. Strategy for Responsible Development-Delegate. Government of Poland (2017). Retrieved from https:// www.delegate.com/.../2017/.../Poland\%20-\%20Pawel

26. Decentralization and multi-level governance in Poland. Ensuring coherence between national and subnational development strategies/policies (2017). Ministry of Development. Retrieved from https://www.oecd. $\mathrm{org} / \mathrm{regional} /$ regional-policy/Decentralisation-and-multi-level-governance-in-Poland.pdf

Стаття надійшла до редакції журналу 01.07.2019. 